\title{
天竜川河口域の出水と波浪による地形変動の観測 \\ O bservation of morphological changes due to floods and waves at the river mouth of Tenryu
}

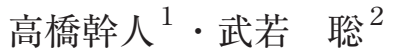 \\ Mikito TAKA HASHI and Satoshi TAKEWAKA
}

\begin{abstract}
M orphological changes at the river mouth of Tenryu by floods and waves are observed continuously with a X-band radar for years 2010 and 2011. X-band radar grasps the shapes of the river channel and sand bar, and the submarine extent of river terrace formed at the seawards of the river mouth. When the river water level increases, flood flow erodes the sand bar, and sediment is fed to expand the river terrace. A fter the flood, recover of the sand bar starts and its tip migrates to close the river by the action of oblique incident waves. At the same time, river terrace starts to shrink also by the action of waves. The amounts of these changes are estimated from the result of $X$-band radar observation and are reasonably well correlated with the flood intensities and wave energy fluxes.
\end{abstract}

\section{1はじめに}

流域から海域に土砂が供給される過程には，次のよう なサイクルがあると理解されている（例えば, 宇多・石 川, 2008）：i）出水により, 河川から海域に供給された 土砂は, 一旦, 河口域に貯留され河口テラスが形成され る. ii）その後, 波浪の作用によりここから沿岸域に土 砂が運ばれ河口テラスが縮小する。このように, 河口域 は沿岸に土砂が波及する起点となっており, その動態を モニタリングすることができれば，沿岸域の侵食の理解 と対策立案の質を高めることが期待できる.

本研究では, ダム再編事業により海域への土砂供給の 増加が期待される天竜川の河口において実施しているX バンドレーダ観測の結果を用い, 出水と波浪の作用に伴 う河口域の土砂移動の規模, 河口テラスの拡大・縮小, 河口砂州先端位置の移動等を示す. 具体的には, 図-1に 概念的に示す河口域の過程を2010年と2011年の観測結果 から示し, 各過程を外力（出水の規模, 波浪）と関連付 けることを試みる. 天竜川では, 出水, 波浪の作用が小 さい時期が続くと河口砂州が発達し, 河口幅が狭まる. 年に数回の規模の出水があると, 河口砂州が浸食されて 河口幅が広がり, 河口の沖合にある河口テラスが拡大す る. その後, 拡大した河口テラスは, 波の作用を受けて 縮小する。宇多ら（2012），三波ら（2013）は深浅測量 データを用い, 天竜川河口周辺の地形変動特性を論じ, 上記の過程を説明している. 本研究の特徴は, 深浅測量 に比較すると精度は劣るが, 連続的に取得された高頻度 の地形データを用い一連のプロセスを説明する点にある.

1 2 正会員 工博

筑波大学大学院システム情報工学研究科 筑波大学教授システム情報系

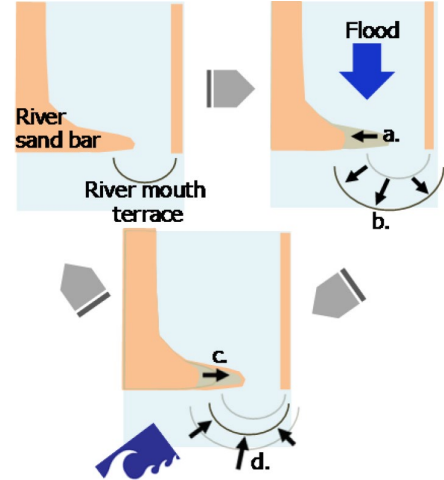

図-1 河口で見られる地形変化のサイクル. 出水時 : a. 河口砂 州の浸食, b. 河口テラスの拡大. 波浪の作用 : c. 河口砂 州の回復, d. 河口テラスの縮小.

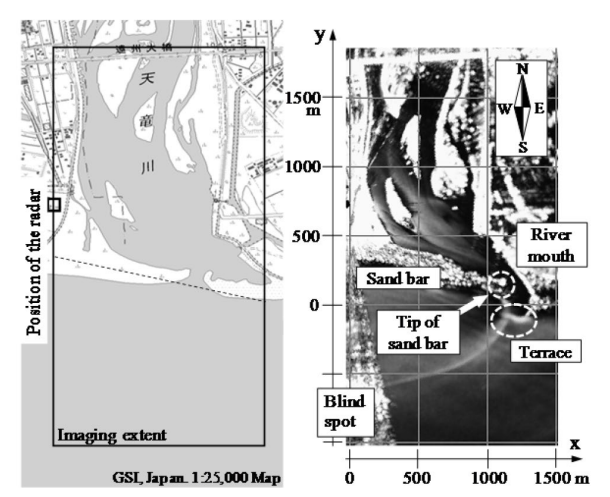

図-2 観測域とレーダ平均画像, 座標系

\section{2 観測の概要}

\section{(1) 対象域と観測方法}

天竜川河口右岸（静岡県浜松市）にある下水処理施設 の屋上にX バンドレーダを設置し2007 年6 月より観測を 


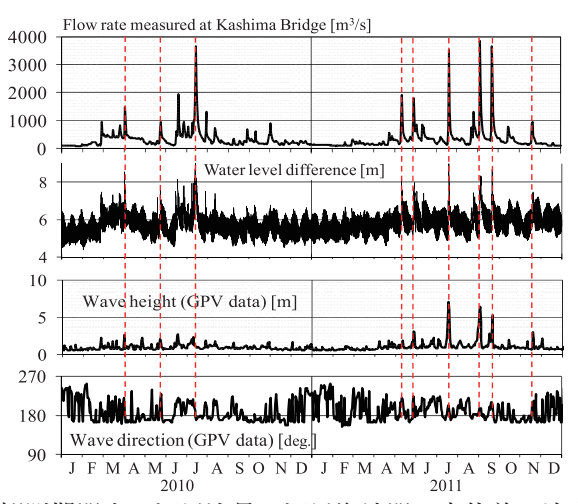

図-3 観測期間中の河川流量, 河川海域間の水位差, 波高, 波 向変化. 破線は解析対象とした出水.

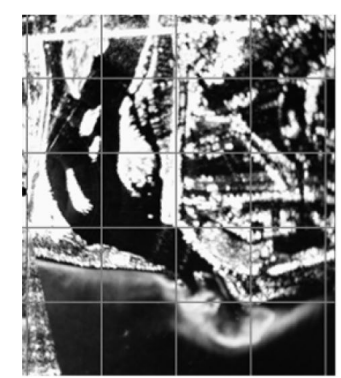

2010/07/1300h

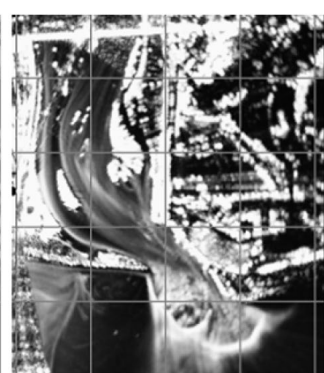

2010/07/1500h
図-4 出水中に取得された平均画像. 2010年7月13日0時(潮位 $0.12 \mathrm{~m}$, 中八町水位 : $7.0 \mathrm{~m}$ ), 2010年7月15日0時 (潮位 : $0.13 \mathrm{~m}$, 中ノ町水位 : $8.8 \mathrm{~m}$ ). 画像中の格子の間隔 : $500 \mathrm{~m}$.

継続している（2014 年5 月時点）。レーダ画像には波の 進行状況，水際位置などが映る。図-2に観測サイト，座 標系, レーダ画像を平均化した平均画像などを示す．座 標系は，東西方向にx軸，南北方向にy軸を設定する，平 均画像は解析に用いる部分を取り出して表示してある. 高輝度の部分が陸域に対応しており, 河道内の砂州, 河 口砂州の形状, 河口フロントの発生, 砕波の状況などを 判読できる. 下水処理施設の塔が妨げとなってレーダエ コーを取得できない領域が扇状に広がっている．平均画 像の処理と解析に関する基本的な説明は前報（高橋ら, 2010）にある.

（2）観測期間中の河川水位と波浪の変化

図-3に2010年，2011年の河川流と波浪の経過を示す. 天竜川鹿島橋（河口より約 $25 \mathrm{~km}$ ）の流量, 天竜川中ノ 町（河口より約 $9 \mathrm{~km}$, 感潮域外）の水位と潮位（御前崎） の差, 気象庁の沿岸波浪数值予報モデル（気象業務セン ター）の河口最寄り位置の計算点の波高・波向の変化を 表示した. 流量が $1000 \mathrm{~m}^{3} / \mathrm{s}$ 超の出水は両年に複数回あっ た. 河川と海域の水位差は土砂移動の規模を評価する際 に用いる．波浪は西方からの入射が多く，高波浪の来襲 は2011年に多かった。 なお, 計算值である波高, 波向と 河口付近の波浪観測結果（静岡県竜洋観測所）を比較し,

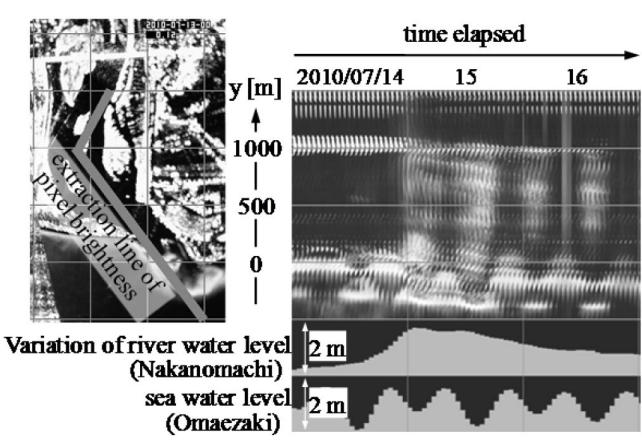

図-5 出水中の河道内の輝度パターン移動速さを計るための ライン画像. (左) 輝度を平均画像より取出したライン. (右)ライン画像. 横軸：時間, 縦軸：流下方向.

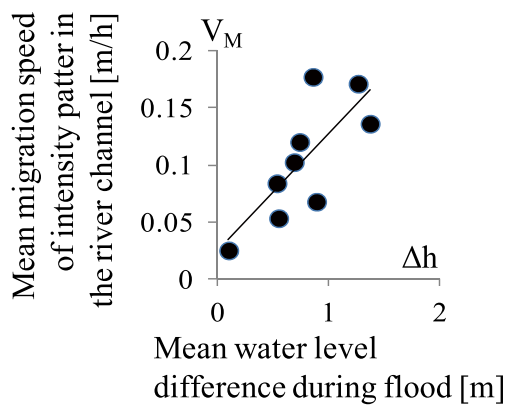

図-6 出水中の平均河川海域間の水位差 $\Delta \mathrm{h}$ 河道内の輝度パ ターンの移動速度 $\mathrm{V}_{\mathrm{M}}$

両者に高い相関性があることを確認している.

\section{3. 河口域の地形変動と外力との関連付け}

河口域では様々な地形の変動過程が見られる. 出水時, レーダ画像の輝度分布には河道内を下流に伝わる特徵的 な時間変化が現れる。これは，河床にあった地形の起伏 の移動を捉えたものと考えられる（武若・高橋, 2011）. これの下流への伝播の規模を指標として, 出水による海 域への土砂供給量を検討する。レーダ画像には，砕波に より河口テラスの縁辺を捉えたとみなせる高輝度部が現 れる.これの分布を読み取り, 潮位・深浅測量の結果と 比較することにより, 河口テラス域の拡大縮小過程を追 跡した. 河口砂州は出水, 高波浪時に侵食され, その後, 静穏期に再び形成される. この再生期の河口砂州先端位 置の移動を追跡した．以下ではそれぞれの過程の詳細と 評価について説明する。

（1）出水時の河道内の土砂移動

出水の最盛期前後の平均画像を詳細にながめると, 河 道内に, 流れ方向に連続的に伝播する輝度パターンの存 在が認められる（図-4). 河道内から海域に土砂が押し出 されている様子が伺え，これは砂堆など，河道にあった 底面地形の凹凸が移動したものの反映であると考えてい る.この輝度パターンの移動速さは, 出水のピーク時に 


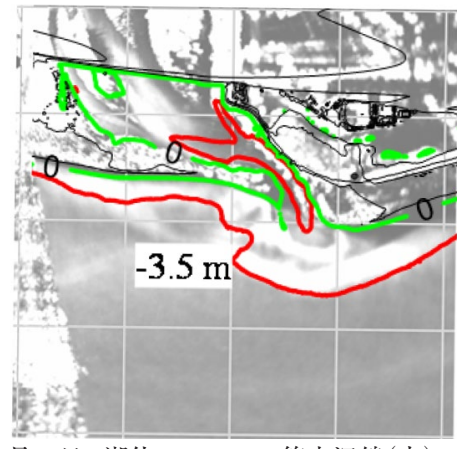

(a) 2010年6月 16 日, 潮位 : $-0.87 \mathrm{~m}$, 等水深線 (赤) : - $3.5 \mathrm{~m}$.

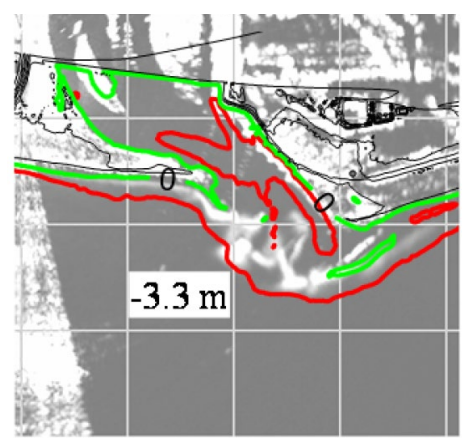

(b) 2010年8月31日, 潮位 : $-0.53 \mathrm{~m}$, 等水深線(赤) : - $3.3 \mathrm{~m}$.

図-7 深浅測量結果と平均画像のオーバレイ. 高輝度部の縁辺 が等水深線 (図中の赤線)に沿って分布している. 画像中 の格子の間隔：500 m.

増加し，また，潮位が上昇し水位勾配が小さくなると低 下するという特徴がある（武若・高橋, 2011).

ここでは，図-3に示した9回の出水時に河道内で見られ た輝度パターンの移動速さと出水の規模を比較し, 輝度 パターンの移動速さが土砂移動を代表する量となり得る かについて検討する.

河道内の流下方向に設けたライン上の輝度分布を画像 の縦方向に展開し, これを観測時間毎に行って画像の横 軸方向に並べた流下方向ライン画像を作成した（図-5). ライン画像中には, 右下方にのびる筋状のパターンが確 認でき,これらは輝度パターンが河道内の流下方向に移 動したことを表している。これらのライン画像中の筋状 パターンの傾き, すなわち, 輝度パターンの移動速さ $\mathrm{V}_{\mathrm{M}}$ をPIV 的な解析から求めた（武若・高橋, 2011). この移 動速さの出水中の総計72時間内の平均を求め, 出水中の 河道内の輝度パターン移動速さとする.

河道内水位（中ノ町）と海域（御前崎）の水位差をh とし, 同量の年間の平均值を $\overline{h_{\text {year }}}$, 同量の出水期間中 の72時間の平均值を $\overline{\mathrm{h}}$ とし, $\Delta \mathrm{h}=\overline{\mathrm{h}}-\overline{h_{\text {year }}}$ という量を 求めた. 河川と海域間の水位差が大きいと土砂輸送の増 大を期待できることから，この量を出水の規模を表す指 標として導入する. 図-6に $V_{M}$ と $\Delta h の$ 関係を示す. 両者に

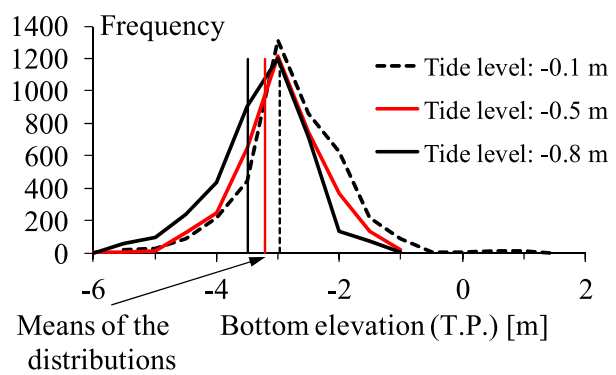

図-8 潮位別の高輝度部縁辺の水深頻度分布. 各潮位における 高輝度部縁辺の平均地盤高さ： 潮位 $-0.1 \mathrm{~m} \rightarrow-3.0 \mathrm{~m}$, 潮位 $-0.5 m \rightarrow-3.2 m$, 潮位 $-0.8 m \rightarrow-3.5 m$

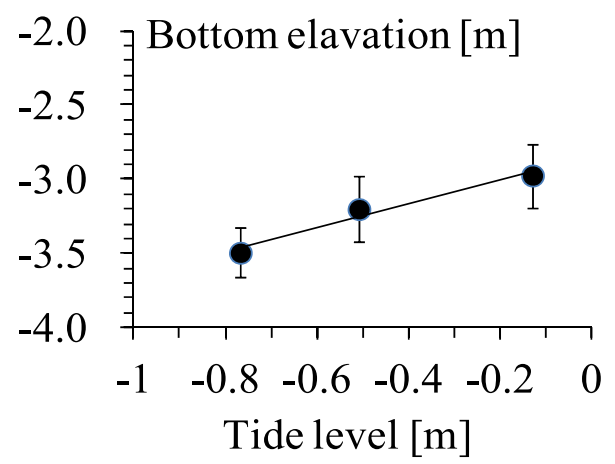

図-9 高輝度部縁辺位置の平均水深と潮位の関係. 縦棒の長さ は潮位別に高輝度部縁辺部の水深を定めた際にあった バラツキの大きさ (RMS值).

は相関が見られ，レーダ画像に捉えられた河道内の輝度 パターンの移動は出水に伴う土砂移動を代表できる可能 性が示された。

\section{（2）河ロテラス縁辺部の水深の推定}

河口テラスの縁辺部で砕波が生じるとこれが高輝度領 域として平均画像に映る. 潮位が異なる時間帯の画像を 調べると, 潮位が高い時には高輝度領域が縮小し, 逆に 低い時には拡大し, 砕波位置が水深により変移する。図 -7は平均画像と深浅測量結果をオーバレイして表示した もので, 高輝度領域の縁辺部はほぼ特定の等水深線水深 に沿って分布することが理解される.

ここでは，2008年から2010年に行われた河口周辺の5 回の深浅測量の結果を用い, 高輝度領域の縁辺部の水深 を潮位別に調べた。 具体的には, 深浅測量が行われた時 期の近くに取得された平均画像から高輝度領域の縁辺部 の位置を読み取り, これらの位置における水深を深浅測 量結果から求めた。御前崎で観測された潮位（T.P.值, 平 均満潮位約 $0.9 \mathrm{~m}$, 平均干潮位約 $-0.8 \mathrm{~m}$ ) を用い, 潮位が0 $\mathrm{m}$ から-0.7 m の時間帯にかけて取得された平均画像を分 析した.

図-8に潮位別に求めた高輝度領域縁辺部の水深の頻度 分布を示す。上記の手順で定めた水深にはばらつきがあ 
る. これは平均画像が取得された時の入射波高, 高輝度 領域縁辺部の海底勾配の違いなどが考慮されておらず, 砕波の発生状況と位置に差異があったためと考えている.

以上のようなばらつきはあるものの, 各頻度分布の単 純平均と潮位の関係（図-9）より, 潮位 $\eta[\mathrm{m}]$ と高輝度領

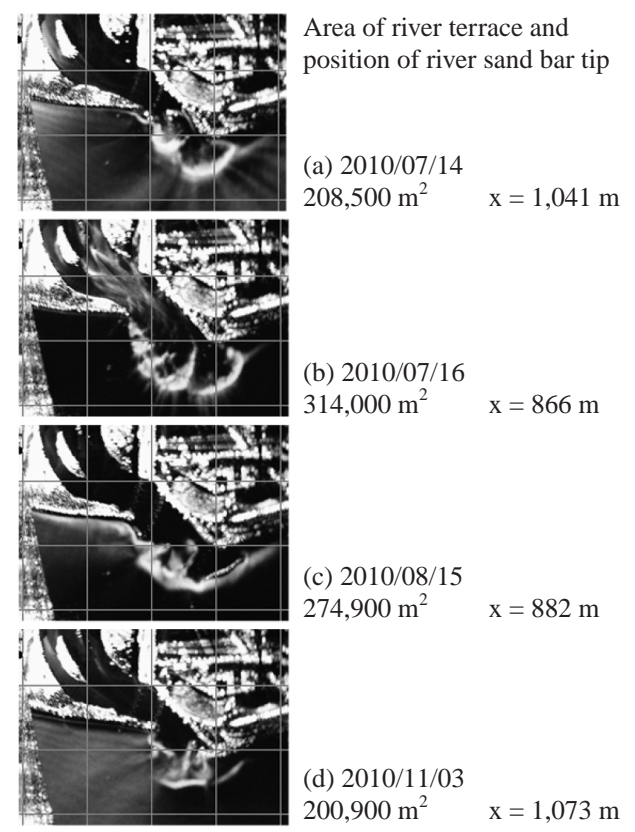

図-10 河口テラス面積と砂州先端位置の変化. (a) 出水前, (b) 出水後(河口テラスの拡大, 河口砂州の浸食), (c), (d) 波 浪の作用による变化河口テラスの縮小, 河口砂州の回復)

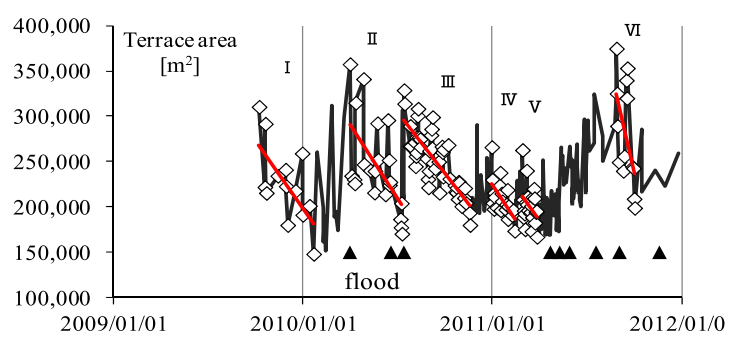

図-11 河口テラス面積変化と変化率を調べた期間 $(\mathrm{I} \sim \mathrm{VI})$. $\diamond:$ 河口テラス面積変化率を求める際に使用したデー夕.
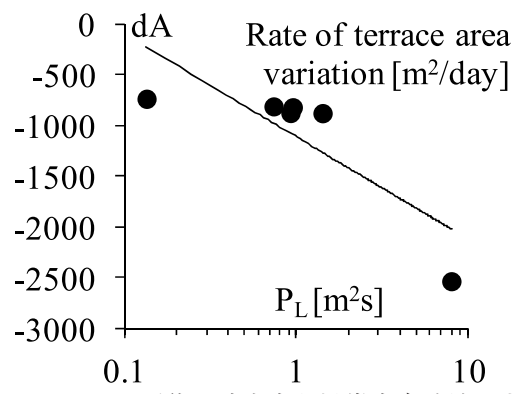

図-12 河口テラス面積の減少率と沿岸方向波浪エネルギー フラックス $\overline{\mathrm{P}_{\mathrm{L}}}$ (正值 : 東向フラックス)の関係

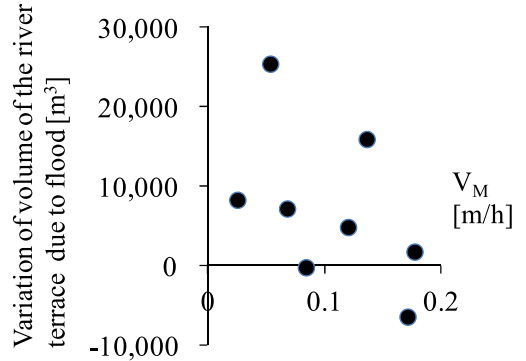

図-13 出水による河口テラス部の土砂量変化（正值：増加）と 河道内の輝度パターンの移動速度 $\mathrm{V}_{\mathrm{M}}$

域縁辺部の地盤高さ $\mathrm{d}[\mathrm{m}]$ の関係を次式で定めた.

$$
d=0.80 \eta-2.9
$$

以降では, この式を用い河口テラス縁辺部の水深を推 定する。

\section{（3）河ロテラスの拡大と縮小}

冒頭に述べた河口付近で見られる地形変化のサイクル の各過程を調べる. 図-10に示すように，出水があると河 口砂州が浸食され河口テラスが拡大する. その後, 河口 砂州が発達し, 河口テラスは縮小する.

河口テラスの縁辺部の位置を潮位がおおよそ $-0.4 \mathrm{~m}$ と なる時間帯に取得された平均画像よりトレースし, その 面積変化を調べた（図-11）。このトレースは500<x< 2,000 mの範囲で行った. 推定された河口テラスの面積は, 平均画像を取得した時間帯の砕波状況の差異による影響 を受け, 変動が大きい. しかしながら, 出水時に河口テ ラスの領域が拡大し, その後, 徐々に縮小するというが 繰り返される過程は捉えられている. 縮小時の面積変化 率 $\mathrm{dAを}$ 同図に示した6期間について求め, 沿岸方向波浪 エネルギーフラックスを代表する量 $\mathrm{P}_{\mathrm{L}}$

$$
P_{L} \sim H^{2} T \sin \theta \cos \theta
$$

のそれぞれの期間中の平均值 $\overline{\mathrm{P}_{\mathrm{L}}}$ と比較した（図-12).こ こでHは数值予報モデルが与える波高, Tは周期, $\theta$ は波 向である. $\theta$ の定義は南からの入射時に $\theta=180^{\circ}$, 西方か らの入射時に $180^{\circ}<\theta<270^{\circ}$ とするので，西方からの波 浪がある時に $\overline{\mathrm{P}_{\mathrm{L}}}>0$ となる. デー夕数が限られているも のの, $\mathrm{dA}$ ¿ $\mathrm{P}_{\mathrm{L}}$ には相関関係があると期待できる. 出水に より形成された河口テラスの土砂がその後の波浪の作用 により河口域外へ運ばれ，河口テラスが縮小している状 況を捉えたと考えている.

先に示した9回の出水前後の河口前面 $(1,000<x<1,500$ m) の河口テラスの地盤高さが-3.5 mから-3 mの範囲の土 砂変化量の推定を試みた。 具体的には, 潮位が $0 \mathrm{~m}$ から $-0.7 \mathrm{~m}$ となる時間帯に取得された複数の平均画像から高 輝度部の縁辺を読み取り, 式（1）を介して河口テラス の地盤高さが-3.5 mから-3 mの範囲の体積を求めた. こ れを出水の前後に行い, 河口テラス部の一部の土砂量変 


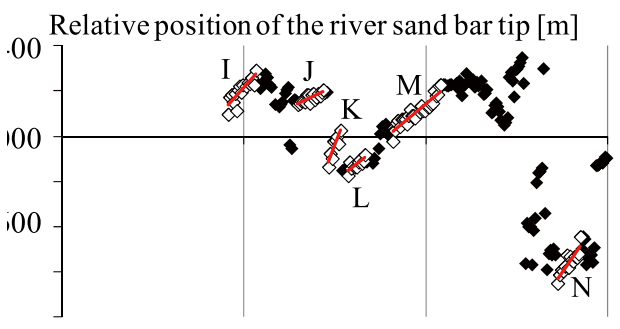

009/01/01 2010/01/01 2011/01/01 2012/01/01

図-14 河口砂州先端位置の変化とその移動速さを調べた期間 $(I \sim N)$. 先端位置 $\diamond)$ は河道内の東西方向の相対的 な位置. 東方が正方向. 白抜きの記号 $(\diamond)$ は各期間の 移動速さ（実線の傾き）を定めるのに使用したデー夕．

化を求め, 先に求めた出水時の河道内の輝度分布移動速 度 $\mathrm{V}_{\mathrm{M}}$ を比較した（図-13）。残念ながら，両者の相関性は 高くない. 土砂量変化を求める範囲を極めて限定したこ と，土砂量を計る深さが限られていることなどより，出 水の影響を十分に捉えていないことに原因があると考元 ている. 出水があると河口前面の河口テラスが形成され る領域が拡大することは確認できているが, 堆積した土 量の見積り方法には改善の余地がある.

\section{（4）出水により浸食された河口砂州の回復}

出水・高波浪があると, 河口砂州が浸食され河口幅が 一気に広がる. その後, 静穏期には河口砂州周辺への堆 砂があり，河口幅は徐々に狭まる，図-14に，レーダの観 測結果から読み取った河口砂州の先端位置（東西方向） の変化を示す，例えば，図-10に示すように，2010年7月 の出水で河口先端位置は175 m西方に後退し, 河口幅は 増加した（期間Kの末期 $\rightarrow$ 期間 Lの初期)。乞の後, 河 口砂州の先端位置は東方に移動し，2010年11月頃には出 水前とほぼ同じ位置となった（期間M）.

図-14に示す6期間の出水後の河口砂州先端位置の西か ら東への移動速さ $\mathrm{V}_{\mathrm{s}}$ を調べ, 沿岸方向波浪エネルギーフ ラックスのそれぞれの期間中の平均值 $\overline{\mathrm{P}}$ と比較した（図 -15). 河口砂州先端位置の移動速さは一日当に数メート ルのオーダである． $V_{\mathrm{S}}$ と $\overline{\mathrm{P}_{\mathrm{L}}}$ には相関関係があると期待で き, 出水後の河口砂州への堆積の一部は沿岸流によるも のと解釈できる. 河口砂州の発達を主に沿岸方向漂砂に より説明できることは，例えば，中山ら（2006）も指摘 している，な扮，河口砂州を踏査した際には，いわゆる 打上げにより顕著な堆積があることをしばしば確認して おり, 河口砂州の形成過程に扔ける岸沖漂砂の寄与を調 べることも必要である.

\section{4. 結び}

本論文では天竜川河口域に見られた一連の地形変動過 程を継続的な観測結果より説明した：a）出水時の土砂移 動を代理的に説明する量を抽出し, 出水の規模と関連付

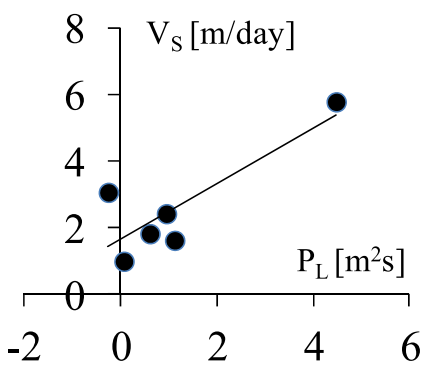

図-15 河口砂州先端位置の移動速さ $\mathrm{V}_{\mathrm{s}}$ と沿岸方向波浪エネル ギーフラックス $\overline{\mathrm{P}_{\mathrm{L}}}$ (正值：東向)の関倸

けた，b）出水により，河口前面の河口テラスが拡大し， 土砂が蓄えられる状況を示した，c）河口テラスが波浪の 作用を受け, 徐々に縮小し, 河口周辺域の土砂供給源と なる過程を捉えた，d）侵食された河口砂州の回復時の先 端の伸長速さと沿岸方向波浪エネルギーフラックスに相 関があることを示した。

沿岸域の土砂管理に貢献するという観点からは, 出水 に伴う河口テラス域の土量変化の見積りをすることが必 要であるが, 本研究では河口テラス域の拡がりの評価を するに留まっている。入射波浪の条件を考慮した砕波帯 の拡がりの検討, 浅海域の波浪変形状況の解析による水 深分布推定などを通じて河口テラス域の水深分布を求 め, 土砂量の変化を評価する手法の開発が必要である.

謝辞：河口周辺の深浅測量デー夕を浜松河川国道事務所 より提供頂いた。本研究は科学研究費 (24656293, 25420516), 河川財団河川整備基金の補助を受けて行わ れた。

\section{参 考 文 献}

宇多高明・石川仁憲（2008）：河口部での土砂移動を安倍川河 口に見る，土木技術資料，Vol. 50，10月号，pp. 58-61.

宇多高明·三波俊郎·石川仁憲・白石慎重・佐藤純一郎 （2012）：天竜川河口部地形の洪水・波浪応答に関する現 地観測, 土木学会論文集B2 (海岸工学), Vol. 68, pp. | 626-1 630 .

気象業務センター：沿岸波浪数值予報モデルGPV (CWM), http://www.jmbsc.or.jp/hp/online/f-online3t.html, 参照201405-09.

三波俊郎 - 宇多高明 - 石川仁憲 - 大井戸志朗 - 遠藤和正 - 佐 藤純一郎 (2013)：天竜川河口右岸の浜松五島海岸で進む 集中的な侵食の実態, 土木学会論文集B2（海岸工学）, Vol.69, pp. I 646-I 650 .

高橋 亮・武若 聡・田島芳満・佐藤㯖司 (2010) : 天竜川河 口域の地形の推移に関する研究, 土木学会論文集B2（海 岸工学), Vol. 66, pp. 596-600.

武若 聡・高橋 亮 (2011)：Xバンドレーダを用いた天竜川 河口域の出水による地形変化の観測, 土木学会河川技術 論文集, Vol.17, pp. 1-4.

中山大輔・田中 仁・山路弘人 (2006)：画像記録装置を用い た河口地形変動の観測とそのモデリング, 海岸工学論文 集, Vol. 53, pp.581-585. 